\title{
A cytosolic factor is required for mitochondrial cytochrome $c$ efflux during apoptosis
}

\author{
Zhiyong Han ${ }^{1}$, Gang $\mathrm{Li}^{1}$, Theodore A. Bremner ${ }^{1,2}$, \\ Thilo S. Lange ${ }^{1}$, Guohong Zhang ${ }^{3}$, Ronald Jemmerson ${ }^{4}$, \\ James H. Wyche ${ }^{1}$ and Eric A. Hendrickson ${ }^{1,5}$ \\ 1 Box G, Department of Molecular Biology, Cell Biology, and Biochemistry, \\ Brown University, Providence, Rhode Island 02912, USA \\ 2 Department of Biology, Howard University, Washington, DC 20059, USA \\ ${ }^{3}$ CLONTECH Laboratories, Inc., 1020 East Meadow Circle, Palo Alto, California \\ 94303, USA \\ ${ }^{4}$ Department of Microbiology, University of Minnesota Medical School, \\ Minneapolis, Minnesota 55455, USA \\ ${ }^{5}$ corresponding author: Eric Hendrickson. tel: 001 401-863-3667; \\ fax 001 401-863-2421; email: eric_hendrickson@brown.edu
}

Received 21.10.97; revised 17.12.97; accepted 8.1.98

Edited by C.J. Thiele

\begin{abstract}
Treatment of HL-60 cells with staurosporine (STS) induced mitochondrial cytochrome $c$ efflux into the cytosol, which was followed by caspase-3 activation and apoptosis. Consistent with these observations, in vitro experiments demonstrated that, except for cytochrome c, the cytosol of HL-60 cells contained sufficient amounts of all factors required for caspase-3 activation. In contrast, treatment of HCW-2 cells (an apoptotic-resistant HL-60 subclone) with STS failed to induce significant amounts of mitochondrial cytochrome $c$ efflux, caspase- 3 activation, and apoptosis. In vitro assays strongly suggested that a lack of cytochrome $c$ in the cytosol was the primary limiting factor for caspase-3 activation in HCW-2 cells. To explore the mechanism which regulates mitochondrial cytochrome $c$ efflux, we developed an in vitro assay which showed that cytosolic extracts from STS-treated, but not untreated, HL-60 cells contained an activity, which we designated 'CIF' (ㄸytochrome $c$-efflux inducing factor), which rapidly induced cytochrome cefflux from $\mathrm{HL}-60$ mitochondria. In contrast, there was no detectable CIF activity in STS-treated HCW-2 cells although the mitochondria from HCW-2 cells were responsive to the CIF activity from STS-treated HL-60 cells. These experiments have identified a novel activity, CIF, which is required for cytochrome $c$ efflux and they indicate that the absence of CIF is the biochemical explanation for the impaired ability of HCW-2 cells to activate caspase-3 and undergo apoptosis.
\end{abstract}

Keywords: caspase-3; cytochrome c; dATP; CIF; apoptosis

Abbreviations: STS, staurosporine; CIF, cytochrome c-efflux inducing factor

\section{Introduction}

One of the key biochemical events in apoptosis is the activation of the caspase family of proteases (Alnemri et al, 1996; reviewed in Salvesen and Dixit, 1997). This activation involves a proteolytic cascade, as all caspase family members are initially synthesized as inactive, single polypeptide precursors and require proteolytic processing themselves to generate the two subunits that form the active protease (Salvesen and Dixit, 1997).

Caspase-3 has been used as the archetypal and most biologically relevant model for caspase activation in part because the activation of caspase- 3 has been observed in many cells under a variety of apoptotic treatments (Darmon et al, 1995; Dubrez et al, 1996; Enari et al, 1996; Erhardt and Cooper, 1996; Han et al, 1996b; Martin et al, 1996; Schlegel et al., 1996). The mature caspase-3 consists of $17 \mathrm{kDa}$ (p17) and $12 \mathrm{kDa}$ (p12) subunits, which are produced from a $32 \mathrm{kDa}$ (p32) precursor (FernandesAlnemri et al, 1994; Nicholson et al, 1995; Tewari et al, 1995a; Liu et al, 1996; Han et al, 1997). Some aspects of the mechanism by which the caspase-3 precursor is converted into the active enzyme are known and in particular endogenous caspase-3 in membrane-free cytosolic extracts from various cell lines can be activated by the addition of exogenous cytochrome $c$ and dATP (Liu et al, 1996; Li et al, 1997) or exogenous cytochrome $c$ alone (Han et al, 1997) under appropriate in vitro assay conditions. Since caspase precursors are present in the cytosol of cells whereas active cytochrome $c$ is located in the mitochondria, these observations suggested that the efflux of cytochrome $c$ from mitochondria into the cytosol during the apoptotic induction process was a key regulatory event in the activation of caspase-3.

An additional important contributor to apoptotic regulation is the Bcl-2 family of proteins (reviewed in Farrow and Brown, 1996; Yang and Korsmeyer, 1996). These proteins can be divided into apoptotic suppressors such as $\mathrm{Bcl}-2$, $\mathrm{Bcl}-\mathrm{x}_{\mathrm{L}}$, and $\mathrm{Mcl}-1$, and apoptosis effectors such as Bax, $\mathrm{Bad}$, Bak, and Bik/Nbk. The apoptotic suppressors are membrane bound, and found predominately in the outer membranes of mitochondria, the endoplasmic reticulum, and the nuclear envelope (Monaghan et al, 1992; Givol et al, 1994; Lithgow et al, 1994). The membrane association of these proteins suggested that they might regulate certain membrane activities. Indeed, purified Bcl-2 (Schendel et al, 1997), Bcl-X $\mathrm{L}_{\mathrm{L}}$ (Minn et al, 1997), or Bax (Antonsson et al, 1997) formed ion channels in membranes. More importantly, the presence of high levels of Bcl-2 protein in mitochondria caused a block in the process of cytochrome $c$ efflux, and, as a consequence, an inhibition of caspase-3 activation and apoptosis (Kluck et al, 1997; Yang et al, 1997). This strongly suggested that the apoptotic suppressive activity of $\mathrm{Bcl}-2$ and $\mathrm{Bcl}-\mathrm{x}_{\mathrm{L}}$ was due directly to their 
inhibitory effect on the process of mitochondria cytochrome $c$ efflux during apoptotic induction. Molecular and biochemical studies have demonstrated that apoptotic suppressors and effectors can physically interact with each other, form heterodimers, and antagonize each other's function (Sato et al, 1994). In particular, Bcl-2 activity is inhibitable by Bad (Yang et al, 1995) and Bax (Oltvai et al, 1993), and that of Bcl- $x_{L}$ by Bad (Yang et al, 1995), Bak (Chittenden et al, 1995; Farrow et al, 1995; Kiefer et al, 1995), and Bax (Boise et al, 1993). Thus, mitochondrial cytochrome $c$ efflux is a critical step in apoptotic induction, and this process appears to be controlled by the interplay of $\mathrm{Bcl}-2$ family members.

We have described the isolation of a stable clonal variant, $\mathrm{HCW}-2$, of the human promyelocytic leukemia cell line, HL-60 (Han et al, 1996a). In striking contrast to the parental cells, which were very apoptotic sensitive, HCW-2 cells were highly resistant to the apoptotic effects of many treatments (Han et al, 1995; 1996a). The resistance of HCW-2 cells to diverse apoptotic treatments suggested that it was unlikely that the cells were defective in multiple individual pathways for the transduction of different apoptotic signals, but rather were defective in a common event(s) that was induced by many apoptotic signal transduction pathways. We demonstrate here that HCW-2 cells are defective in the caspase- 3 activation process due to a lack of mitochondrial cytochrome $c$ efflux during apoptotic induction. In addition, we discovered the presence of a cytochrome $c$-efflux inducing factor (CIF) in HL-60 cells, which was activated by staurosporine (STS) treatment and able to induce mitochondrial cytochrome $c$ efflux in an in vitro assay system. CIF activity was not detected in HCW-2 cells. CIF is thus identified as an important regulator of cytochrome $c$ efflux and the lack of CIF in HCW-2 cells results in a severe block in the mitochondrial cytochrome $c$ efflux process and thus the inability of these cells to activate caspase-3 and apoptosis.

\section{Results}

\section{The status of caspases in HL-60 and HCW-2 cells during apoptotic induction}

The status of caspase-1, caspase-2, and caspase- 3 in $\mathrm{HL}$ 60 and HCW-2 cell lines during apoptotic induction by STS was investigated. Both cell lines expressed detectable caspase-2 and caspase-3 but not caspase-1 (Figure 1A). In untreated cells, caspase- 2 and caspase-3 existed, as expected, as inactive precursors in the cytosol. Treatment of HL-60 cells with $5 \mu \mathrm{M}$ STS for $4 \mathrm{~h}$ selectively induced proteolytic activation of caspase-3 as demonstrated by the disappearance of the caspase-3 precursor (p32) and the appearance of the $\mathrm{p} 17$ subunit of the mature caspase- 3 (Figure 1A). In addition, caspase-3 activity was easily detected in the HL-60 cytosol (Figure 1B). In contrast, with the same treatment, neither caspase-2 nor caspase-3 were activated in $\mathrm{HCW}-2$ cells (Figure $1 \mathrm{~A}$ and $\mathrm{B}$ ). DAPI staining of HL-60 cells treated with STS for $4 \mathrm{~h}$ revealed that almost all of the cells were apoptotic as illustrated by granular
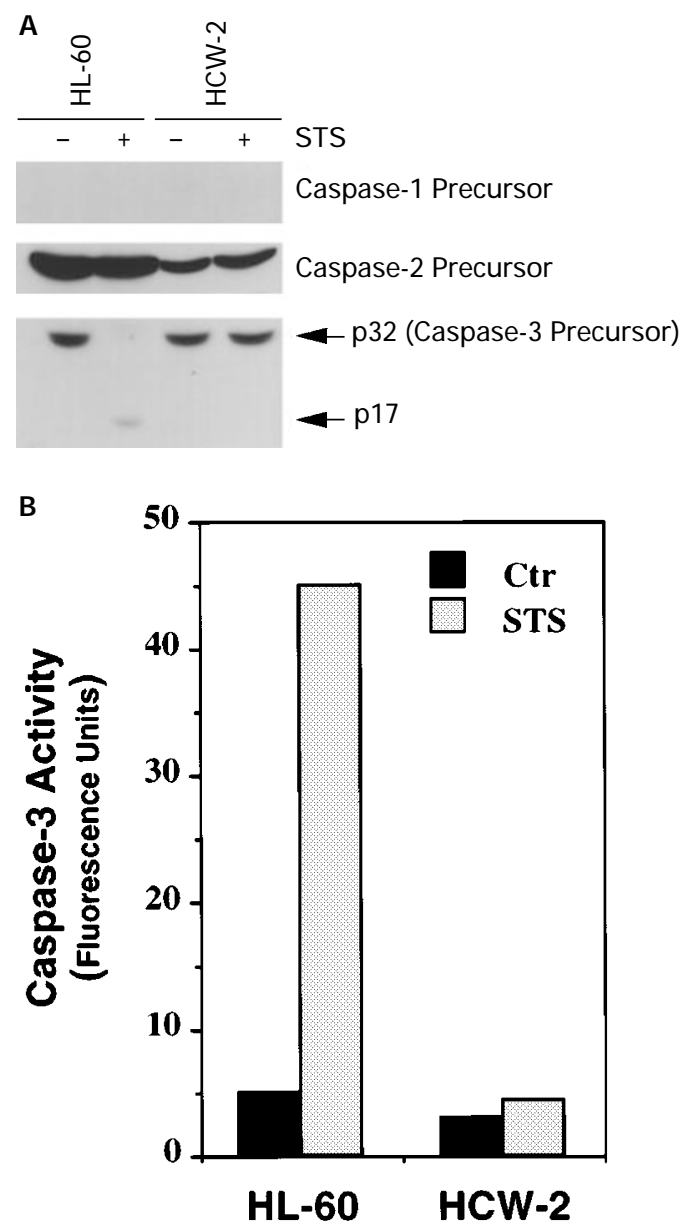

Figure 1 Selective activation of caspase- 3 in HL-60 cells during apoptosis induction. HL-60 and HCW-2 cells were either left untreated or treated with $5 \mu \mathrm{M}$ STS for $4 \mathrm{~h}$ and S-100 cytosolic extract was prepared from the cells. (A) Western blot analyses of the status of caspase-1, caspase-2, and caspase- 3 in the cells during STS treatment. The caspase- 3 precursor is indicated as p32, and the mature subunit of the active caspase- 3 is indicated as p17. (B) Caspase-3 activity in the S-100 extract from untreated (Ctr) and STS-treated (STS) cells. Activity was measured using the CLONTECH ApoAlert ${ }^{\text {TM }}$ CPP32 Fluorescent Assay Kit as described in Materials and Methods

bodies of highly condensed DNA in the nuclei (compare Figure $2 \mathrm{~A}$ and $\mathrm{B}$ ). DAPI staining of STS-treated HCW-2 cells revealed no signs of apoptosis (compare Figure $2 \mathrm{C}$ and D). Thus, the apoptotic-resistant phenotype of HCW-2 cells was associated with a defect(s) in the pathway leading to caspase-3 activation.

\section{In vitro caspase-3 activation using cytosolic extracts from HL-60 and HCW-2 cells}

We next attempted to determine the limiting factors for caspase- 3 activation in $\mathrm{HL}-60$ and $\mathrm{HCW}-2$ cells using S100 cytosolic extracts and an in vitro caspase-3 activation assay (Liu et al, 1996; Han et al, 1997; Li et al, 1997). The addition of cytochrome $c$ to the S-100 cytosolic extract from HL-60 cells induced proteolytic activation of the endogen- 

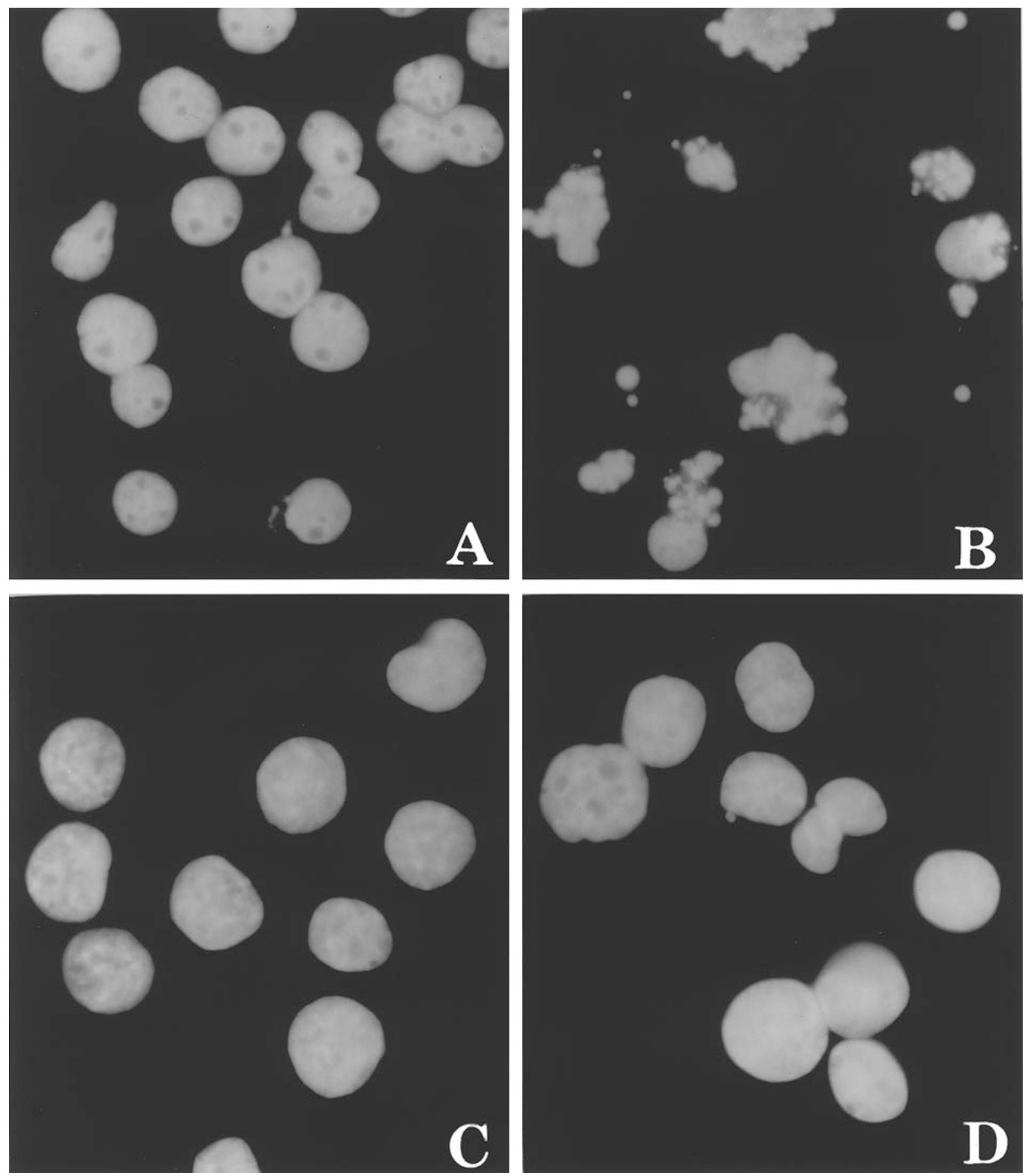

Figure 2 Identification of apoptotic cells by DAPI staining. HL-60 (A, B) and HCW-2 (C, D) cells were either left untreated (A, C) or were treated with $5 \mu \mathrm{M}$ STS for $4 \mathrm{~h}$ (B, D). The cells were fixed, stained with $100 \mathrm{ng} / \mathrm{ml}$ DAPI and then the cells were washed and photographed using a fluorescent microscope

ous caspase- 3 as illustrated by the disappearance of the $32 \mathrm{kDa}(\mathrm{p} 32)$ precursor of caspase-3 and the appearance of the $17 \mathrm{kDa}$ (p17) subunit of the mature caspase-3 in Western blot analyses (Figure 3). Thus, the cytosol of HL60 cells contained sufficient amounts of all factors, with the sole exception of cytochrome $c$, for caspase-3 activation.
Unexpectedly, caspase-3 processing also occurred with HCW-2 extracts (Figure 3). In contrast to HL-60 cells, activation of the endogenous caspase- 3 in the HCW-2 S-100 cytosolic extract was not only dependent upon exogenous cytochrome $c$ but also required exogenous dATP (Figure 3). These results strongly suggested that the 
apoptotic defect in HCW-2 cells was not in caspase-3 itself, but in an upstream signalling event since extracts derived from HCW-2 cells were permissive for the induction of caspase-3 whereas intact HCW-2 cells were refractory.

\section{Mitochondrial cytochrome $c$ efflux in HCW-2 cells is blocked during apoptotic induction}

Cytochrome $c$, which normally resides within the mitochondria, must be extruded into the cytosolic compartment prior to caspase-3 activation (Kluck et al, 1997; Yang et al, 1997). Correspondingly, we observed that treatment of HL-60 cells with STS induced a time-dependent accumulation of cytochrome $c$ in the cytosol (Figure 4A), which preceded activation of caspase-3 (Figure $4 A$ and $B$ ). The accumulation of cytochrome $c$ in the cytosol of STS-treated HL-60 cells correlated well with the loss of mitochondrial cytochrome $c$ (Figure 4C). In contrast, treatment of HCW-2 cells with STS resulted in the appearance of very little cytochrome $c$ in the cytosol, which correlated with an insignificant loss of mitochondrial cytochrome $c$ (Figure $4 \mathrm{C}$ ). Thus, the mitochondrial cytochrome $c$ efflux process in HCW-2 cells was severely defective and this provided an explanation for the inability of these cells to activate caspase- 3 .

\section{Activation of a cytosolic cytochrome c-efflux inducing factor (CIF)}

To study the regulation of the mitochondrial cytochrome $c$ efflux process we developed an in vitro assay system (see Materials and Methods). Incubation of purified mitochondria from HL-60 cells with the S-100 cytosolic extract from STStreated $(5 \mu \mathrm{M}, 1 \mathrm{~h}) \mathrm{HL}-60$ cells rapidly induced complete cytochrome $c$ efflux (Figure $5 \mathrm{~A}$ ). Incubation of mitochondria with buffer or the S-100 cytosolic extract from untreated HL-60 cells failed to induce cytochrome $c$ efflux (Figure 5A). Thus, treatment of HL-60 cells with STS activated a specific cytosolic factor(s), which we termed 'CIF' (ytochrome $c$ efflux inducing factor).

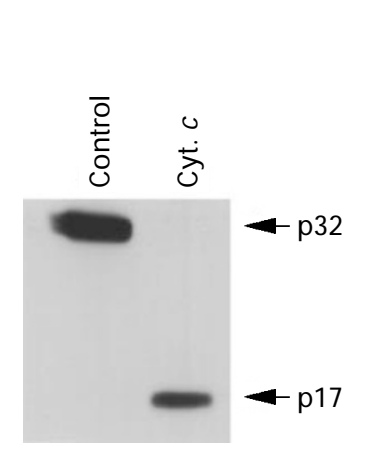

HL-60

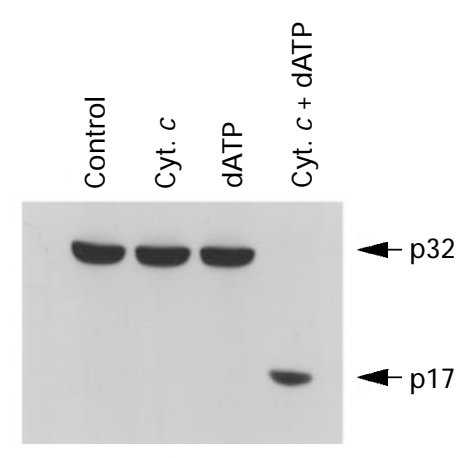

HCW-2
Figure 3 In vitro activation of the endogenous caspase- 3 in the S-100 extracts from HL-60 and HCW-2 cells. HL-60 or HCW-2 S-100 extracts $(200 \mu \mathrm{g})$ were incubated with an aliquot of buffer alone (Control), $0.4 \mu \mathrm{g}$ o cytochrome $c$ (Cyt. $c$ ), $1.5 \mathrm{mM}$ dATP, or a combination of cytochrome $c$ and dATP for $60 \mathrm{~min}$ at $37^{\circ} \mathrm{C}$ (see Materials and Methods). The reaction mixtures were then subjected to Western blot analyses. p32 indicates the $32 \mathrm{kDa}$ caspase- 3 precursor and $\mathrm{p} 17$ indicates the mature $17 \mathrm{kDa}$ caspase- 3 subunit
Incubation of the S-100 cytosolic extract at $45^{\circ} \mathrm{C}$ for 60 min completely inactivated CIF activity (Figure 5B) whereas the presence of up to $2 \mathrm{mM}$ thio-ATP (S-ATP), a non-hydrolyzable ATP analog, had no effect on CIFinduced mitochondrial cytochrome $c$ efflux (Figure 5C). Therefore, CIF activity was highly heat-labile and apparently independent of ATP hydrolysis.
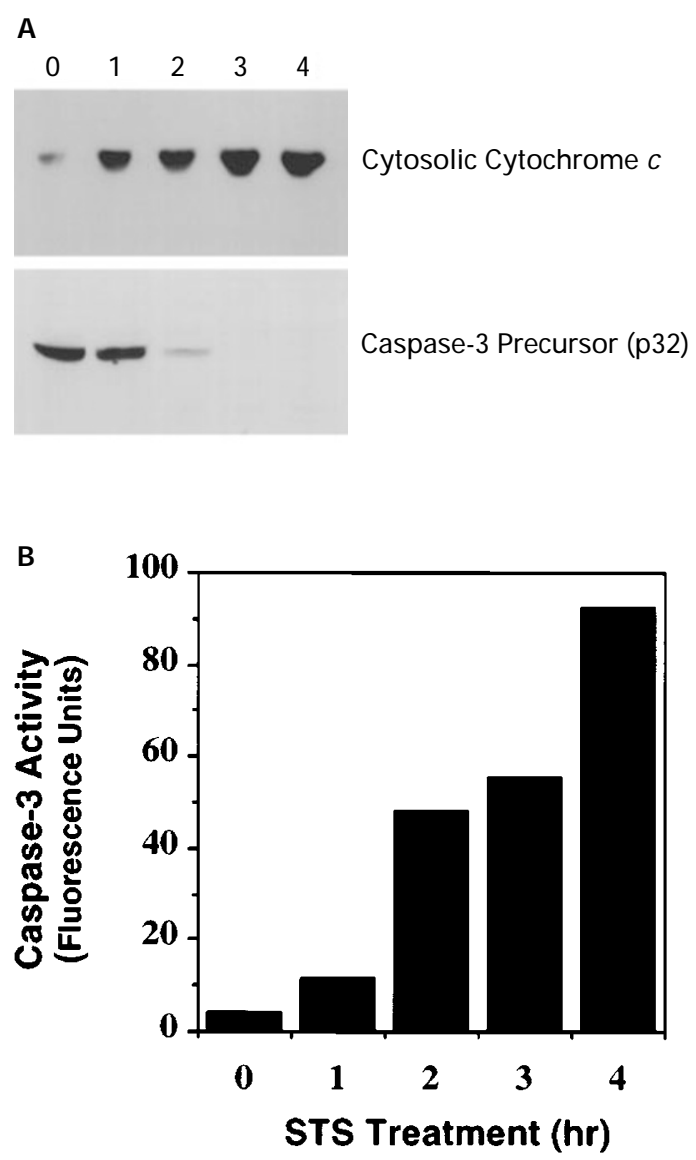

C

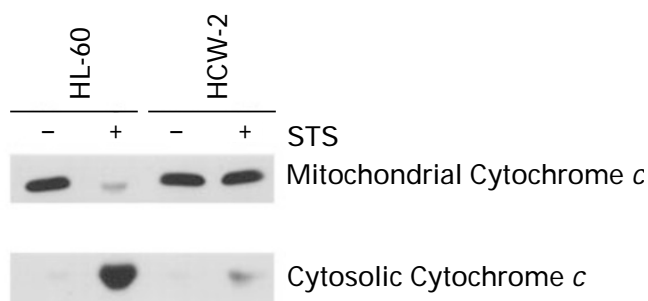

Figure 4 Kinetics of cytosolic cytochrome $c$ accumulation and caspase-3 activation. (A) Equal numbers of HL-60 cells were either left untreated (0) or were treated with $5 \mu \mathrm{M}$ STS for $1,2,3$ and $4 \mathrm{~h}$. After each treatment, the S-100 cytosolic extract was prepared from the cells. The samples were then subjected to Western blot analyses for cytochrome $c$ and caspase-3. (B) Alternatively, the presence of caspase- 3 activity was measured using the caspase-3 activity assay (see Materials and Methods and Figure 1). (C) STS induces mitochondrial cytochrome $c$ efflux in HL-60 but not in HCW-2 cells. Equal numbers of HL-60 and HCW-2 cells were either left untreated or were treated with $5 \mu \mathrm{M} \mathrm{STS} \mathrm{for} 4 \mathrm{~h}$. The cells were then fractionated into cytosolic and mitochondrial fractions and subjected to Western blot analyses for cytochrome $c$ 
A

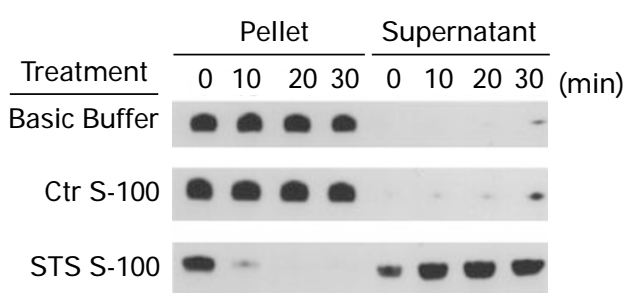

B

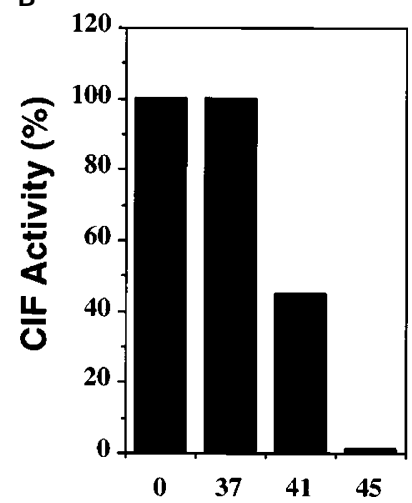

Temperature
C

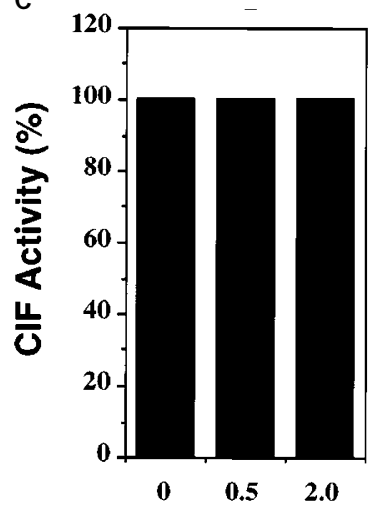

S-ATP (mM)

Figure 5 Characterization of CIF. (A) CIF induces mitochondrial cytochrome $c$ efflux in vitro. Purified mitochondria from HL-60 cells were incubated either with basic buffer (basic buffer), S-100 extract from untreated HL-60 cells (Ctr S-100), or the S-100 extract from HL-60 cells that had been treated with $5 \mu \mathrm{M}$ STS for $1 \mathrm{~h}$ (STS S-100) for the indicated times. At the end of each incubation, the reaction mixture were separated into pellet (mitochondria) and supernatant. The cytochrome $c$ distribution in these two fraction was then analyzed by immunoblotting. Note that the STS S-100 (supernatant, 0 min lane) already contained cytochrome $c$ due to STS-induced mitochondrial cytochrome $c$ efflux into the cytosol in HL-60 cells prior to the preparation of the S-100 extract. (B) CIF activity is heat-labile. Freshly prepared STS S-100 from HL-60 cells was left on ice $\left(0^{\circ} \mathrm{C}\right)$, or incubated at 37,41 , or $45^{\circ} \mathrm{C}$ for $60 \mathrm{~min}$. The samples were centrifuged at $12500 \times \mathrm{g}$ for $5 \mathrm{~min}$ to remove denatured proteins. The supernatant was used to incubate mitochondria for $15 \mathrm{~min}$ at $37^{\circ} \mathrm{C}$ to test the presence of CIF activity. (C) CIF activity is independent of ATP hydrolysis. The STS S-100 extract was incubated without or with $0.5 \mathrm{mM}$, or $2 \mathrm{mM}$ of thio-ATP (S-ATP) for $10 \mathrm{~min}$ at $20^{\circ} \mathrm{C}$ and then CIF activity was determined

CIF does not alter the amounts of Bcl-2, Bad, Bak, and Bax proteins in mitochondria

Cytochrome $c$ efflux during apoptosis induction is believed to be regulated by the Bcl-2 family of proteins (Kluck et al, 1997; Yang et al, 1997). Therefore, the status of Bcl-2, Bax, Bad, and Bak proteins in HL-60 mitochondria before and after treatment with CIF (i.e, the S-100 from STS-treated HL-60 cells) was determined. CIF-induced cytochrome $c$ efflux from purified HL-60 cell mitochondria did not cause detectable changes in the levels of the mitochondrial-associated $\mathrm{Bcl}-2$, Bad, Bak, and Bax proteins (Figure 6).

\section{HCW-2 cells lack CIF activity}

The lack of cytochrome $c$ efflux in HCW-2 cells during apoptosis induction (Figure 4C) suggested that either (i)

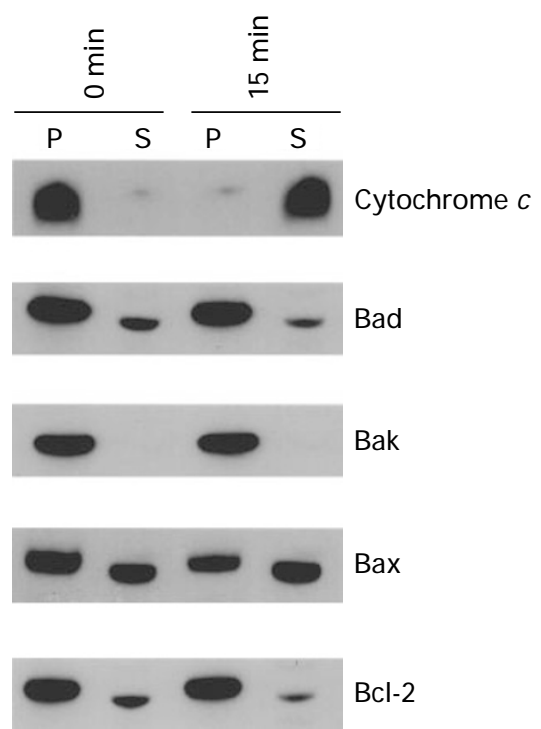

Figure 6 CIF activity does not alter the amount of mitochondrial-associated $\mathrm{Bcl}-2$, Bad, Bak, and Bax proteins. Mitochondria from $\mathrm{HL}-60$ cells were incubated for 0 or 15 min with the S-100 extract from HL-60 cells that had been treated with $5 \mu \mathrm{M}$ STS for $1 \mathrm{~h}$. The samples were then separated into the supernatant (S) and mitochondrial pellet $(\mathrm{P})$. The status of cytochrome $c$, Bad, $\mathrm{Bak}, \mathrm{Bax}$, and Bcl-2 were determined by Western blot analyses

HCW-2 mitochondria were highly resistant to CIF activity or (ii) that HCW-2 cells lacked CIF activity. To experimentally test these hypotheses we performed heterologous cytochrome $c$ efflux assays. When HCW-2 cell mitochondria were incubated with S-100 cytosolic extract from STS-treated HL-60 cells cytochrome $c$ efflux was rapidly induced (Figure 7A). In addition, when S-100 cytosolic extract from either untreated or STS-treated HCW-2 cells was incubated with HL-60 cell mitochondria no efflux of cytochrome $c$ was observed (Figure 7B). Together, these results strongly suggested that HCW-2 cells lacked CIF activity and that the absence of this activity was directly related to the lack of cytochrome $c$ efflux and consequently to the lack of caspase- 3 activation and the apoptotic-resistant phenotype of HCW-2 cells.

\section{dATP levels in the S-100 extracts from HL-60 and HCW-2 cells}

Finally, we investigated why activation of caspase-3 in the S100 extract from HCW-2 cells required not only cytochrome $c$ but also exogenous dATP whereas caspase-3 activation in the S-100 extract from HL-60 cells required only the addition of exogenous cytochrome $c$ (Figure 3). The dATP requirement was dose-dependent, and a minimum of $100 \mu \mathrm{M}$ exogenous dATP was required for a significant amount of the endogenous caspase-3 in the HCW-2 S-100 cytosolic extract to be activated in the presence of cytochrome $c$ (Figure $8 \mathrm{~A}$ ). The dATP requirement appeared to be very specific, because no other deoxynucleotides or nucleotides could replace its function (Figure 8B).

The non-requirement for exogenous dATP in the caspase-3 activation assay using the HL-60 S-100 
cytosolic extract (Figure 3) suggested either that HL-60 cells already contained a sufficient amount of dATP in the cytosol to meet the requirement for caspase-3 activation or that the reaction was dATP independent. To test these hypotheses, the effect of apyrase, which metabolizes deoxynucleoside or nucleoside di- and triphosphates into deoxynucleoside or nucleoside monophosphates (Lebel et al, 1980; Laliberte et al, 1983) on the process of cytochrome c-dependent activation of the endogenous caspase-3 in the HL-60 S-100 cytosolic extract was investigated. As a control, the effect of $5^{\prime}$-nucleotidase, which converts deoxnucleoside or nucleoside monophosphates into deoxynucleosides or nucleosides, was also investigated. When apyrase, but not $5^{\prime}$-nucleotidase, was added to the S-100 cytosolic extracts from HL-60 cells, subsequent addition of cytochrome $c$ to the assay system no longer induced caspase-3 activation (Figure $8 \mathrm{C}$ ). This result suggested that dATP was also required for the activation of caspase-3 in the HL-60 S-100 cytosolic extract and that the lack of the need to add exogenous dATP to these extracts was probably due to a sufficient endogenous level.

To confirm this hypothesis, we determined the concentration of dATP in the HL-60 and HCW-2 extracts. The dATP concentration in the S-100 extracts from HL-60 and HCW-2 cells was $409.5 \mu \mathrm{M}$ and $98.3 \mu \mathrm{M}$, respectively (Table 1). Using these values, the concentration of the endogenous dATP in the caspase- 3 activation assay was calculated to be $327.6 \mu \mathrm{M}$, and $78.6 \mu \mathrm{M}$ for HL-60 and HCW-2 cells, respectively (Table 1 ). These results indicated that, unlike the parental HL-60 cells, HCW-2 cells contained a much lower level of dATP in their cytosol. This low level of dATP in the HCW-2 S-100 extract may be the reason why exogenous dATP was required for the activation of caspase-3 in vitro.

A

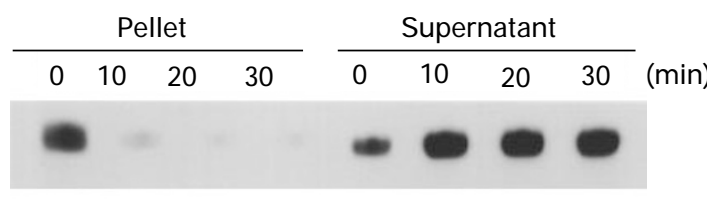

B

\begin{tabular}{|c|c|c|c|c|c|}
\hline \multicolumn{3}{|c|}{ Pellet } & \multicolumn{3}{|c|}{ Supernatant } \\
\hline 0 & 10 & $\overline{30}$ & 0 & 10 & 20 \\
\hline
\end{tabular}

Ctr S-100

$\infty+\infty+\infty+\infty$

STS S-100

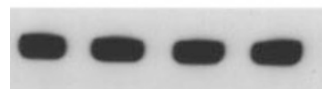

Figure $7 \mathrm{HCW}-2$ mitochondria are responsive to CIF activity. (A) Incubation of the S-100 from STS-treated HL-60 cells with purified mitochondria from HCW-2 cells rapidly induced cytochrome $c$ efflux. (B) HCW-2 cells lack CIF activity. S-100 extract was prepared from untreated HCW-2 cells (Ctr S-100) or HCW-2 cells that had been treated with $5 \mu \mathrm{M}$ STS for $2 \mathrm{~h}$ (STS S-100), and used in an incubation with purified mitochondria from HL-60 cells for $0,10,20$ or $30 \mathrm{~min}$ at $37^{\circ} \mathrm{C}$. The status of cytochrome $c$ was then determined by immunoblot analysis

\section{Discussion}

Caspase-3 was selectively activated in HL-60 cells undergoing apoptosis and the activation process was preceded and mediated by mitochondrial cytochrome $c$ efflux into the

A

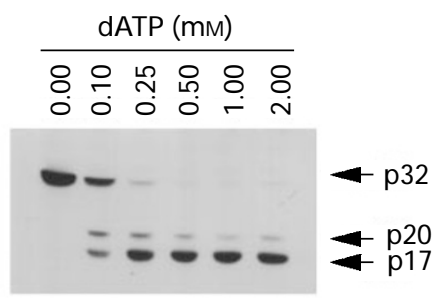

B $\bar{O}$

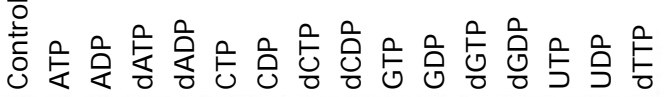

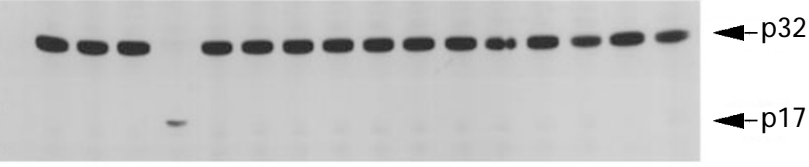

C

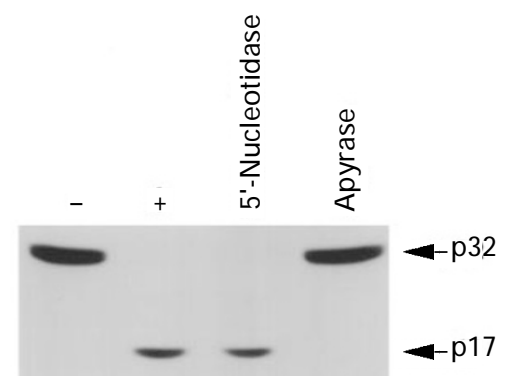

Figure 8 The dATP requirement for caspase-3 activation. (A) In the caspase3 activation assay (Figure 3 ), the HCW-2 cell S-100 extract was supplemented with $0.4 \mu \mathrm{g}$ of cytochrome $c$ alone or various concentrations of dATP. The $32 \mathrm{kDa}$ precursor of caspase- 3 is indicated as p32. p20 indicates an intermediate product derived from $\mathrm{p} 32$, which is then converted into the mature $\mathrm{p} 17$ subunit during the caspase-3 activation process (Han et al, 1997). (B) In the caspase-3 activation assay, the HCW-2 cell S-100 extract was supplemented with $0.4 \mu \mathrm{g}$ cytochrome $c$ and either incubated with an aliquot of buffer alone (Control) or with $1.5 \mathrm{mM}$ of the indicated compound. (C) Inhibition of the cytochrome $c$-dependent activation of the endogenous caspase- 3 in the S-100 extract from HL-60 cells by apyrase. In the caspase-3 activation assay the S-100 extract from HL-60 cells was incubated with buffer $(-)$ or $0.4 \mu \mathrm{g}$ cytochrome $c(+)$ for $60 \mathrm{~min}$ at $37^{\circ} \mathrm{C}$. Alternatively, the S-100 extract was first incubated with $50 \mathrm{mU} 5^{\prime}$-nucleotidase, or $50 \mathrm{mU}$ apyrase for $5 \mathrm{~min}$ at $20^{\circ} \mathrm{C}$. Then, $0.4 \mu \mathrm{g}$ cytochrome $c$ was added to each sample and the incubation continued at $37^{\circ} \mathrm{C}$ for $60 \mathrm{~min}$. The reaction mixtures were then subjected to a Western blot analysis for caspase-3

Table 1 Endogenous dATP Concentrations in the S-100 Extracts from HL-60 and HCW-2 cells

\begin{tabular}{lcc}
\hline Cells & $\begin{array}{c}\text { dATP } \\
\text { concentration in the } \\
\text { final S-100 Extract }\end{array}$ & $\begin{array}{c}\text { Endogenous dATP } \\
\text { concentration in the } \\
\text { caspase-3 activation assay }\end{array}$ \\
\hline HL-60 & $409.5 \pm 46.3 \mu \mathrm{M}$ & $327.6 \pm 37.0 \mu \mathrm{M}$ \\
HCW-2 & $98.3 \pm 22.0 \mu \mathrm{M}$ & $78.6 \pm 17.6 \mu \mathrm{M}$ \\
\hline
\end{tabular}

The data represent the average of five independent experiments 
cytosol. Therefore, regulation of mitochondrial cytochrome $c$ efflux was the limiting step for caspase- 3 activation and thus apoptotic induction in HL-60 cells. Furthermore, we developed a reliable assay for studying how mitochondrial cytochrome $c$ efflux is regulated. Using this assay, we have identified a heatlabile, STS-activatable cytosolic factor (termed CIF) in HL-60 cells, which rapidly induced mitochondrial cytochrome $c$ efflux. Apoptotic-resistant HCW-2 cells failed to activate caspase- 3 because there was a severe block in the mitochondrial cytochrome $c$ efflux process, which was associated with a lack of CIF activity. Therefore, the apoptotic phenotypes of HL-60 and HCW-2 cells appeared to be a function of cytochrome $c$ efflux regulation by $\mathrm{CIF}$ and the ultimate ability or inability, respectively, to activate caspase-3.

\section{The lack of CIF activity correlates with the apoptotic-resistant phenotype of HCW-2 cells}

$\mathrm{HL}-60$ cells are extremely sensitive to the apoptotic effects of many different chemical and physical treatments (Martin et al, 1990; Boe et al, 1991; Ishida et al, 1992; Gong et al, 1993; Bertrand et al, 1994; Kiguchi et al, 1994; Han et al, 1995; 1996a). The HCW-2 cell line was isolated originally as a stable clonal variant of HL-60 by virtue of the cell's ability to survive a long-term treatment with 8-chloro-adenosine 3', 5'cyclic monophosphate (Han et al, 1996a). Subsequently, HCW-2 cells were also found to be highly resistant to the apoptotic effect of other chemical and physical treatments including cycloheximide or STS exposure, and X-irradiation (Han et al, 1995; 1996a). Such a resistance profile indicated that HCW-2 cells were unlikely to be defective in the signal transduction pathways that mediate the apoptotic effect of each individual treatment. Rather, a defect(s) in the centralized apoptotic signal transduction pathway was most likely to be responsible for this phenotype. In particular, caspase-3 activation occurs in many cell lines under a variety of apoptotic conditions (Darmon et al, 1995; Tewari et al, 1995a; Dubrez et al, 1996; Enari et al, 1996; Erhardt and Cooper, 1996; Han et al, 1996b; Martin et al, 1996; Schlegel et al, 1996). Importantly, it had also been shown that the inhibition of caspase-3 activity in cells could block apoptosis (Darmon et al, 1995; Tewari et al, 1995b; Dubrez et al, 1996; Enari et al, 1996; Martin et al, 1996; Schlegel et al, 1996). Our results strongly suggest that the apoptotic-resistant phenotype of HCW-2 cells is due to their inability to activate caspase-3 during apoptosis. This is not due to a defect in caspase-3 per se (Figure 3) but due to the lack of CIF and the related inability to flux mitochondrial cytochrome $c$ into the cytosol (Figure 7B).

The in vitro activation of endogenous caspase- 3 in the cytosolic extract from HL-60 cells did not require exogenous dATP (Figure 3). This was due to the presence of high levels of endogenous dATP in the extract (Figure $8 \mathrm{C}$ and Table 1). In contrast, activation of caspase- 3 in the S-100 extract from HCW-2 cells was dependent on both exogenous cytochrome $c$ and dATP (Figure 3). Thus, at first glance, it appeared that the small dATP pool size in the S-100 extract from HCW-2 cells (Table 1) correlated well with the cells' in vivo inability to activate caspase-3. However, although small in comparison with HL-60 cells, the actual dATP pool size in HCW-2 cells may not be a limiting factor for caspase-3 activation in vivo. The concentration of endogenous dATP in the caspase-3 activation assay using the HCW-2 S-100 extract was calculated to be approximately $78.6 \mu \mathrm{M}$ (Table 1). In a typical assay, when the S-100 extract from HCW-2 cells was used, at least $100 \mu \mathrm{M}$ of additional exogenous dATP was required for the activation of a significant amount of caspase-3 (Figure 8A). This suggested that the presence of approximately $180 \mu \mathrm{M}$ dATP is required for caspase-3 activation. However, when the S-100 extract was prepared from HCW-2 cells, the ratio of the final lysate volume to the volume of the original wet cell pellet was at least $2: 1$ (see Materials and Methods). This corresponds to a twofold dilution of the cytosolic components in the S-100 extract. If this dilution factor is taken into consideration, then the actual dATP concentration in the cytosol of intact HCW-2 cells should be at least $160 \mu \mathrm{M}$. Accordingly, at this dATP concentration significant caspase-3 activation can probably occur when a sufficient amount of cytochrome $c$ is available (Figure 8A). Therefore, the dATP pool size in HCW-2 cells may not be a limiting factor for caspase-3 activation in vivo.

\section{Cytochrome $c$ efflux and CIF}

The original finding (Liu et al, 1996) that cytochrome $c$ was required for caspase- 3 activation indicated that mitochondrial cytochrome $c$ efflux should play a key role in apoptotic regulation, since biologically active cytochrome $c$ protein is localized in the intermembrane space of mitochondria. Indeed, an early event during apoptotic induction in HL-60 cells is the efflux of mitochondrial cytochrome $c$ into the cytosol, which is followed by caspase-3 activation (Yang et al, 1997). More interestingly, this process appeared to be regulated by the $\mathrm{Bcl}-2$ family of proteins. Specifically, mitochondria in HL-60 cells that contained an excess amount of $\mathrm{Bcl}-2$ protein due to ectopic over-expression of the gene were blocked in cytochrome $c$ efflux (Yang et al, 1997). These studies suggested that the ability of apoptotic suppressors such as $\mathrm{Bcl}-2$ and $\mathrm{Bcl}-\mathrm{x}_{\mathrm{L}}$ to block apoptosis was directly due to their ability to block mitochondrial cytochrome $c$ efflux, and thus caspase-3 activation. In this study, we show that CIF, a cytosolic factor, also plays a significant regulatory role for mitochondrial cytochrome $c$ efflux during apoptosis. CIF's salient features are: (i) its activity was not found in cells under normal conditions (Figure 4C and 5); (ii) it was rapidly activated by STS (Figure 4C, 5 and 7); (iii) it was very heat labile (Figure $5 \mathrm{~B}$ ); (iv) it did not require ATP hydrolysis (Figure $5 \mathrm{C}$ ); (v) it did not alter the amount of mitochondrial membrane associated $\mathrm{Bcl}-2$ family proteins (Figure 6); and (vi) it was not detected in HCW-2 cell cytosol (Figure 7B).

Therefore, we envision that treatment of HL-60 cells with STS activates CIF, which then interacts with specific mitochondrial proteins and induces cytochrome $c$ efflux. The consequences are caspase- 3 activation and apoptosis (Figure 9). This hypothesis suggests that $\mathrm{Bcl}-2$ and related proteins may be downstream targets of CIF. Thus, CIF may inactivate $\mathrm{Bcl}-2$, either by directly binding to it or by modifying the protein in some unknown fashion and this 
should facilitate the efflux of cytochrome $c$ from the mitochondria. If such a Bcl-2: CIF interaction does take place it apparently does so without affecting the size, stability or location of mitochondrial Bcl-2 (Figure 6). When $\mathrm{Bcl}-2$ is in excess of CIF, mitochondria may be resistant to $\mathrm{CIF}$. This is consistent with the observation that Bcl-2overexpressing HL-60 cells are blocked in the process of cytochrome $c$ efflux (Yang et al, 1997). Currently, numerous cell death effector molecules including Bax (Oltvai et al, 1993), Bad (Yang et al, 1995), Bcl-x (Boise et al, 1993), Bik/Nbk (Boyd et al, 1995; Han et al, 1996), Bid (Wang et al, 1996), and Hrk (Inohara et al, 1997) are known to interact with $\mathrm{Bcl}-2$ and antagonize its activity. Therefore, some of these proteins may fulfill the function of CIF. Since HL-60 cells do not express the $b c l-x$ gene (Han et al, $1996 \mathrm{a}), \mathrm{Bcl}-\mathrm{x}_{\mathrm{S}}$ is an unlikely candidate. In addition, the mitochondria of HL-60 cells contain Bax and Bad proteins under normal (non-induced) conditions and are therefore unlikely to be candidates for CIF (Figure 6). The most interesting candidates for CIF could be Bik/Nbk, Bid, and/or Hrk. In particular, it has been demonstrated that overexpression of Bik/Nbk (Boyd et al, 1995; Han et al, 1996), Bid (Wang et al, 1996), or Hrk (Inohara et al, 1997) in cells by itself causes cell death without subjecting the cells to an apoptotic treatment. Since Bik/Nbk, Bid, and Hrk interact with and antagonize the biological function of $\mathrm{Bcl}-2$, it could be speculated that one or more of these proteins may inhibit mitochondrial $\mathrm{Bcl}-2$ activity and directly induce cytochrome $c$ efflux, thus causing caspase-3 activation and apoptosis. We are currently using the in vitro cytochrome $c$ efflux assay to assess whether Bik/Nbk, Bid or Hrk is consistent with being CIF.

Another plausible hypothesis is that $\mathrm{CIF}$ and $\mathrm{Bcl}-2$ compete with each other for binding to the same target

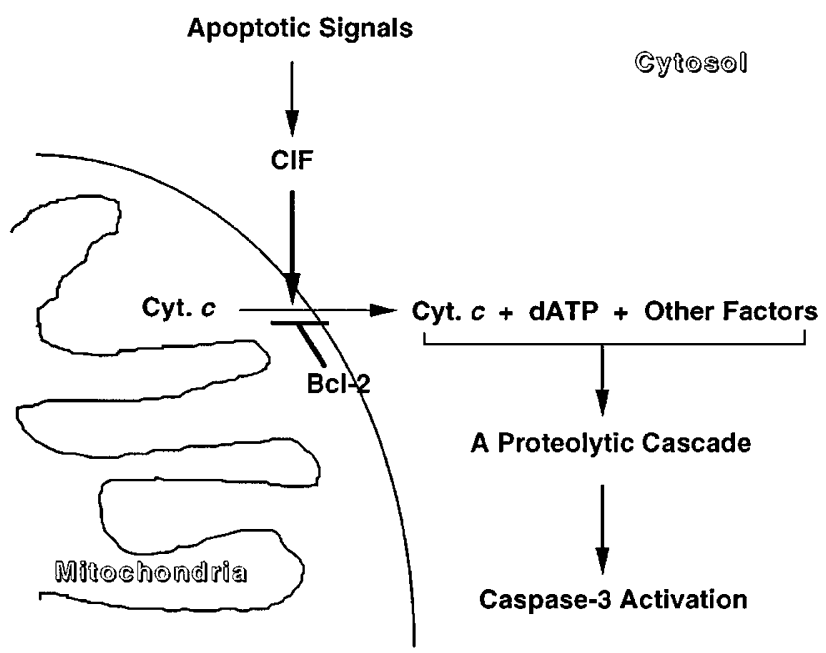

Figure 9 A model for apoptotic induction in HL-60 cells. The model shows that CIF activity lies upstream of cytochrome $c$ efflux within the cell death pathway. It is anticipated that $\mathrm{Bcl}-2$ antagonizes CIF activity at a site on the outer membrane of mitochondria. The efflux of cytochrome $c$ into the cytosol then activates a proteolytic cascade leading to the activation of caspase-3 (Han et al, 1997; Li et al, 1997) as long as the dATP concentration is sufficient and other appropriate factors are available protein in the membrane of mitochondria. The results of CIF or Bcl-2 binding, however, would have different biological results. Thus, binding of $\mathrm{Bcl}-2$ to the target protein would block, whereas binding of CIF would facilitate, cytochrome $c$ efflux. In this regard, mitochondrial Bax and Bad would be strong candidates for the target protein. This model is also attractive since it would explain why the simple overexpression of Bax (Oltvai et al, 1993) or Bad (Yang et al, 1995) in cells does not result in apoptosis, but is still dependent upon apoptotic induction.

In summary, we have characterized a biochemical pathway which is essential for apoptotic induction triggered by STS in HL-60 cells (Figure 9). In addition, we have identified the defect in the apoptotic resistant $\mathrm{HCW}-2$ cell line as a failure to flux cytochrome $c$. Lastly, and most importantly, we have demonstrated that HL-60 cells possess a cytoplasmic activity, CIF, that appears to be required for cytochrome $c$ efflux. The further characterization of CIF should greatly facilitate our understanding of the apoptotic mechanism.

\section{Materials and Methods}

\section{Materials}

Fetal bovine serum (FBS), EDTA, phenylmethylsulfonyl fluoride (PMSF), aprotinin, antipain, leupeptin, purified cytochrome $c$ from rat heart, and dATP were purchased from Sigma Chemical, Co (St Louis, MO). Staurosporine (STS) was purchased from Kamiya Biomedical Co. (Seattle, WA). The Complete ${ }^{\mathrm{TM}}$ protease inhibitor cocktail tablets were purchased from Boehringer Mannheim Co (Indianapolis, IN). One tablet was dissolved in $50 \mathrm{~mL}$ solution to give a $1 \times$ concentration of the protease inhibitors. The caspase- 3 activity assay reagents (ApoAlert ${ }^{\mathrm{TM}}$ CPP32 Fluorescent Assay Kits) were produced by CLONTECH Laboratories, Inc. (Palo Alto, CA). Human caspase-1 antibodies were purchased from Oncogene Sciences, Inc. (Uniondal, NY). Human caspase-2 and caspase-3 antibodies were purchased from Transduction Laboratories, Inc. (Lexington, KY). Monoclonal antibodies against cytochrome $c$ have been described (Jemmerson et al, 1991). Protein quantitation reagents were purchased from Bio-Rad Laboratories, Inc. (Hercules, CA). ECL Western blot analysis reagents were purchased from Amersham Life Science, Inc. (Arlington Heights, IL).

\section{Cells}

HL-60 and HCW-2 cells were cultured in RPMI 1640 medium supplemented with $20 \%$ and $10 \%$ FBS, respectively. The medium also contained $100 \mathrm{U} / \mathrm{ml}$ penicillin and $50 \mathrm{U} / \mathrm{ml}$ streptomycin. Cells were incubated at $37^{\circ} \mathrm{C}$ in a humidified incubator with $5 \% \mathrm{CO}_{2}$.

\section{Mitochondrial cytochrome $c$ efflux and caspase-3 activation during apoptosis}

Cells $\left(1 \times 10^{8}\right)$ were left untreated or treated with $5 \mu \mathrm{M}$ STS for $0,1,2$, 3 or $4 \mathrm{~h}$. At the end of each treatment, cells were pelleted by centrifugation and washed in $50 \mathrm{~mL}$ of phosphate-buffered saline (PBS) once. The cells were then incubated in $1 \mathrm{ml}$ of the lysis buffer (10 mM HEPES, pH 7.5, $5 \mathrm{mM} \mathrm{MgCl} 2,1 \mathrm{mM}$ DTT, $1 \mathrm{mM}$ PMSF, $50 \mu \mathrm{g} / \mathrm{ml}$ each of leupeptin, aprotinin and antipain) on ice for $10 \mathrm{~min}$. 
The cells were broken by five passages through a syringe fitted with a 25-gauge needle. The lysate was divided into two equal parts. To isolate mitochondria, the lysate was mixed with $13.5 \mathrm{ml}$ of lysis buffer containing $0.25 \mathrm{M}$ sucrose. The mixture was centrifuged at $500 \times \mathrm{g}$ for $10 \mathrm{~min}$ at $4^{\circ} \mathrm{C}$ to pellet nuclei. The supernatant was then recentrifuged at $10000 \times \mathrm{g}$ for $10 \mathrm{~min}$ at $4^{\circ} \mathrm{C}$, and the pellet was used as the mitochondrial preparation. The other half of the initial lysate was immediately centrifuged at $12500 \times g$ for $5 \mathrm{~min}$ at $4^{\circ} \mathrm{C}$ to pellet nuclei and mitochondria. The pellet was discarded and supernatant was then centrifuged at $100000 \times g$ for $30 \mathrm{~min}$ at $4^{\circ} \mathrm{C}$. The clarified supernatant (S-100) was used as the cytosolic extract. Fifty $\mu$ l aliquots of the S-100 extracts were stored at $-80^{\circ} \mathrm{C}$ for the caspase-3 activity assay. The mitochondrial or cytosolic fractions were lysed in a final volume of $600 \mu \mathrm{l}(10 \%$ glycerol, $5 \% \quad \beta$-mercaptoethanol, and $2 \%$ SDS), and heated at $100^{\circ} \mathrm{C}$ for $5 \mathrm{~min}$. Samples were then electrophoresed in $12 \%$ polyacrylamide gels, and blotted onto nitrocellulose filters. Cytochrome $c$ and caspases were detected using ECL Western blot reagents.

\section{In vitro caspase-3 activation assay}

Concentrated S-100 cytosolic extract was prepared as described above, except that the ratio of the cell pellet volume to lysis buffer volume was $1: 1$. The extract was adjusted to $10 \mu \mathrm{g}$ protein $/ \mu$ l plus $5 \%$ glycerol and stored in small aliquots at $-80^{\circ} \mathrm{C}$. To activate caspase-3, $20 \mu \mathrm{l}$ of the S-100 extract was mixed with $2 \mu \mathrm{l}$ of cytochrome $c(0.2 \mu \mathrm{g} / \mu \mathrm{l}), 1 \mu \mathrm{l}$ of an EDTA stock solution $(187 \mathrm{mM})$, and $2 \mu \mathrm{l}$ of dATP stock solutions at various concentrations or $2 \mu \mathrm{l}$ of $\mathrm{H}_{2} \mathrm{O}$ to replace the dATP. The mixture was then incubated at $37^{\circ} \mathrm{C}$ for $1 \mathrm{~h}$. The reaction was terminated by the addition of $6 \mu \mathrm{l}$ of $5 \times$ SDS sample loading buffer and heated at $100^{\circ} \mathrm{C}$ for $5 \mathrm{~min}$. The samples were then subjected to SDS-polyacrylamide gel electrophoresis and Western blot analyses (Han et al, 1997). Alternatively, $20 \mu \mathrm{l}$ of the reaction mixture was used for a caspase- 3 activity measurement using the ApoAlert ${ }^{\mathrm{TM}}$ CPP32 fluorescent assay (CLONTECH Laboratories, Inc.). The caspase-3 activity was quantitated by fluorescence at $505 \mathrm{~nm}$.

\section{In vitro mitochondrial cytochrome $c$ efflux assay}

Concentrated S-100 cytosolic extract was prepared from cells as described above. The extract was adjusted to $10 \mathrm{mg} / \mathrm{ml}$ protein plus $50 \mathrm{mM} \mathrm{KCl}, 5 \mathrm{mM}$ EDTA, and $2.5 \times$ of the Complete ${ }^{\mathrm{TM}}$ protease inhibitor cocktail, and stored in small aliquots at $-80^{\circ} \mathrm{C}$. To purify mitochondria, cells were washed in PBS three times. The cell pellet was resuspended in two volumes of a $5 \mathrm{mM} \mathrm{MgCl} 2$ solution, and incubated on ice for $2 \mathrm{~min}$. The cells were lysed by being passed through a 25-gauge needle three times. The lysate was immediately mixed with $25 \mathrm{ml}$ of a $0.88 \mathrm{M}$ sucrose $/ 5 \mathrm{mM} \mathrm{MgCl} 2$ solution. The mixture was centrifuged at $1400 \times g$ for $10 \mathrm{~min}$ at $4^{\circ} \mathrm{C}$ to pellet the nuclei. The supernantant was re-centrifuged at $26000 \times g$ for $10 \mathrm{~min}$ at $4{ }^{\circ} \mathrm{C}$ to pellet the mitochondria. The supernatant was discarded and the mitochondrial pellet was resuspended in a $0.25 \mathrm{M}$ sucrose/ $5 \mathrm{mM} \mathrm{MgCl} 2$ solution and incubated on ice for $5 \mathrm{~min}$. During this incubation period, an aliquot of the suspension was diluted into $2 \mathrm{ml}$ of the $0.25 \mathrm{M}$ sucrose solution and the $\mathrm{OD}_{520}$ absorption of this diluted mitochondria suspension was determined. Following this, the stock mitochondria suspension was adjusted to an $\mathrm{OD}_{520}$ equivalence of approximately 18. Aliquots of $80 \mu \mathrm{l}$ of the mitochondrial suspension were pipeted into microcentrifuge tubes and the mitochondria were pelleted at $12500 \times \mathrm{g}$ for $1 \mathrm{~min}$ at $4^{\circ} \mathrm{C}$. The supernatant was discarded. The mitochondria were resus- pended in $100 \mu \mathrm{l}$ of washing buffer (10 mM HEPES, pH 7.5, $50 \mathrm{mM}$ $\mathrm{KCl}, 5 \mathrm{mM}$ EDTA), incubated on ice for $2 \mathrm{~min}$, and centrifuged at $12500 \times g$ for $1 \mathrm{~min}$ to pellet mitochondria. The supernatant was removed and the mitochondria were immediately used for experiments. Mitochondria were incubated in $20 \mu \mathrm{l}$ of basic buffer (10 mM HEPES, pH 7.5, $1 \mathrm{mM}$ DTT, $1 \mathrm{mM} \mathrm{PMSF,} 50 \mu \mathrm{g} / \mu \mathrm{l}$ each of antipain, aprotinin, and leupeptin, $5 \mathrm{mM} \mathrm{MgCl}_{2}, 5 \mathrm{mM}$ EDTA, $2.5 \times$ of the Complete ${ }^{T M}$ protease inhibitor Cocktail, $50 \mathrm{mM} \mathrm{KCl}$ ) or the $\mathrm{S}$ 100 extract at $37^{\circ} \mathrm{C}$ for various lengths of time. To terminate the incubation, the tubes were centrifuged at $12500 \times g$ for $1 \mathrm{~min}$. The supernatant was mixed with $5 \mu \mathrm{L}$ of $5 \mathrm{X}$ SDS-loading buffer, the pellet was dissolved in $25 \mu \mathrm{l}$ of $1 \times$ SDS-loading buffer, and the samples were heated at $100^{\circ} \mathrm{C}$ for $5 \mathrm{~min}$. A $10-\mu$ l aliquot of each sample was subjected to electrophoresis in a $12 \%$ polyacrylamide gel and subsequently analyzed by immunoblot analysis for the presence of cytochrome $c$.

\section{DAPI staining of cells}

Cells were washed in PBS once and fixed in $2 \%$ paraformadehyde$0.1 \%$ Triton X-100 PBS solution for $30 \mathrm{~min}$ at $4^{\circ} \mathrm{C}$. The cells were then washed in PBS three times. Cells were stored at $4^{\circ} \mathrm{C}$ in PBS or spun onto slides in a cytospin centrifuge. Cells were stained in PBS containing $100 \mathrm{ng} / \mathrm{ml} \mathrm{DAPI}$ for $10 \mathrm{~min}$. The slides were then washed in PBS three times and nuclei staining with DAPI were observed under a fluorescent microscope. Apoptotic cells were identified as those with densely stained granular nuclear bodies.

\section{Quantitative analysis of the dATP content in the S-100 extracts}

The method originally described by Solter and Handschumacher (1969) for quantitative determination of deoxynucleoside triphosphates in cell extracts was adapted and modified for this study. Briefly, $4 \mu \mathrm{l}$ of Hindll digested lambda DNA $(0.5 \mu \mathrm{g} / \mu \mathrm{l})$ was mixed with $5 \mu \mathrm{l}$ of random hexamer oligonucleotides $(100 \mathrm{ng} / \mu \mathrm{l})$ and $6 \mu \mathrm{l}$ of $\mathrm{H}_{2} \mathrm{O}$ in $1.5 \mathrm{ml}$ microfuge tubes and incubated at $100^{\circ} \mathrm{C}$ for $5 \mathrm{~min}$. The tubes were then immediately placed on ice for $5 \mathrm{~min}$ and subsequently shifted to room temperature for another $5 \mathrm{~min}$. To determine the dATPdependent incorporation of $\left[\alpha{ }^{32} \mathrm{P}\right] \mathrm{dCTP}$ into DNA, $5 \mu \mathrm{l}$ of $5 \times$ reaction buffer (250 mM Tris- $\mathrm{HCl}, \mathrm{pH} 8.0,50 \mathrm{mM} \mathrm{MgCl} 2,1 \mathrm{mM} \mathrm{dCTP}, 1 \mathrm{mM}$ dGTP, $1 \mathrm{mM} \mathrm{dTTP})$ and $1 \mu \mathrm{l}$ of $\left[\alpha^{32} \mathrm{P}\right] \mathrm{dCTP}(3000 \mathrm{Ci} / \mathrm{mmol}, 3.3 \mu \mathrm{M})$ were added to the tubes. In addition, $2 \mu \mathrm{l}$ of $\mathrm{H}_{2} \mathrm{O}$ and/or dATP was added to the mixture to give a final concentration of $0,5,10,25$, or $50 \mu \mathrm{M}$ dATP. To determine the amount of dATP in the cellular S-100 extracts, the dATP was replaced by $2 \mu \mathrm{l}$ of the S-100 extract with various dilutions. Klenow DNA polymerase solution $(2 \mu \mathrm{l}$ at $2.5 \mathrm{U} / \mu \mathrm{l})$ was then added to each tube and the mixtures were incubated at $37^{\circ} \mathrm{C}$ for $5 \mathrm{~min}$. The reactions were stopped by the addition of $0.5 \mathrm{ml}$ of icecold $20 \%$ trichloroacetic acid (TCA) solution to the tubes. Sonicated salmon sperm DNA ( $100 \mu \mathrm{l}$ of $5 \mathrm{mg} / \mathrm{ml}$ ) was added to each tube as carrier DNA. The contents were mixed, incubated on ice for $60 \mathrm{~min}$ and then centrifuged at $12500 \times g$ for $10 \mathrm{~min}$ at $4^{\circ} \mathrm{C}$. The supernatant was discarded and the pellet was extracted with $1 \mathrm{ml}$ of the TCA solution on ice for $60 \mathrm{~min}$. Finally, the tubes were centrifuged at $12500 \times g$ for $10 \mathrm{~min}$ at $4^{\circ} \mathrm{C}$. The TCA solution was removed, the tip of the tube which contained the DNA pellet was cut off, and the radioactivity in the pellet was determined by scintillation counting. $A$ standard curve of a linear relationship between the amount of dATP and $\left[\alpha-{ }^{32} \mathrm{P}\right] \mathrm{dCTP}$ incorporation (c.p.m.) into DNA was obtained and this and the amount of radioactive incorporation into DNA using the $S$ 100 extract were used to determine the concentration of dATP in the extracts. 


\section{Acknowledgements}

This work is supported in part by a National Science Foundation grant MCB-9630362 (to JHW and EAH), and by a National Institute of Health grant Al 35763 (to EAH). EAH is a Leukemia Society of America Scholar. TB is supported by a Visiting Associate Professor Fellowship from the Howard Hughes Medical Institute to Brown University (grant \#5-29251). We thank Drs. A.-K. Bielinsky and D. Chatterjee for their comments and helpful discussions.

\section{References}

Alnemri ES, Livingston DJ, Nicholson DW, Salvesen G, Thornberry NA, Wong WW and Yuan J (1996) Human ICE/CED-3 protease nomenclature. Cell 87: 171

Antonsson B, Conti F, Ciavatta A, Montessuit S, Lewis S, Martinou I, Bernasconi L, Bernard A, Mermod J-J, Mazzei G, Maundrell K, Gambale F, Sadoul R and Martinou J-C (1997) Inhibition of Bax channel-forming activity by Bcl-2. Science 277: $370-372$

Bertrand R, Solary E, O'Connor P, Kohn KW and Pommier Y (1994) Induction of a common pathway of apoptosis by staurosporine. Exp. Cell Res. 211: 314-321

Boe R, Gjertsen BT, Vintermyr OK, Houge G, Lanotte M and Doskeland SO (1991) The protein phosphatase inhibitor okadaic acid induces morphological changes typical of apoptosis in mammalian cells. Exp. Cell Res. 195: 237-246

Boise LH, Gonzalez-Garcia M, Postema CE, Ding L, Lindsten T, Turka LA, Mao X, Nunez $G$ and Thompson CB (1993) bcl-X, a bcl-2-related gene that functions as a dominant regulator of apoptotic cell death. Cell 74: 597-608

Boyd JM, Gallo GJ, Elangovan B, Houghton AB, Malstrom S, Avery BJ, Ebb RG Subramanian T, Chittenden T, Lutz RJ and Chinnadurai G (1995) Bik, a novel death-inducing protein shares a distinct sequence motif with $\mathrm{Bcl}-2$ family proteins and interacts with viral and cellular survival-promoting proteins. Oncogene 11 $1921-1928$

Chittenden T, Harrington EA, O'Connor R, Flemington C, Lutz RJ, Evan Gl and Guild BC (1995) Induction of apoptosis by the bcl-2 homologue bak. Nature 374: 733736

Darmon AJ, Nicholson DW and Bleackley RC (1995) Activation of the apoptotic protease CPP32 by cytotoxic T-cell-derived granzyme B. Nature 377: 446-448

Dubrez L, Savoy I, Hamman A and Solary E (1996) Pivotal role of a DEVD-sensitive step in etoposide-induced and Fas-mediated apoptotic pathways. EMBO J. 15: $5504-5512$

Enari M, Talanian RV, Wong WW and Nagata S (1996) Sequential activation of ICElike and CPP32-like proteases during Fas-mediated apoptosis. Nature 380: 723-726

Erhardt P and Cooper GM (1996) Activation of the CPP32 apoptotic protease by distinct signaling pathways with differential sensitivity to $\mathrm{Bcl}-\mathrm{x}_{\mathrm{L}}$. J. Biol. Chem. 271: $17601-17604$

Farrow SN, White JHM, Martinou I, Raven T, Pun K-T, Grinham CJ, Martinou J-C and Brown R (1995) Cloning of a bcl-2homologue by interaction with adenovirus E1B 19K. Nature 374: $731-733$

Farrow SN and Brown R (1996) New members of the Bcl-2 family and their protein partners. Curr. Opin. Genet. Dev. 6: 45-49

Fernandes-Alnemri T, Litwack G and Alnemri ES (1994) CPP32, a novel human apoptotic protein with homology to Caenorhabditis elegans cell death protein Ced-3 and mammalian interleukin-1 $\beta$-converting enzyme. J. Biol. Chem. 269: 30761-30764.

Givol I, Tsarfaty I, Resau J, Rulong S, Da Silva PP, Nasioulas G, DuHadaway J, Hughes SH and Ewert DL (1994) Bcl-2 expression using a retroviral vector is localized primarily in the nuclear membrane and the endoplasmic reticulum of chicken embryo fibroblasts. Cell Growth Differ. 5: 419-429

Gong J, Li X and Darzynkiewwicz Z (1993) Different patterns of apoptosis of HL-60 cells induced by cyclohexamide and camptothecin. J. Cell. Physiol. 157: 263270

Han J, Sabbatini P and White E (1996) Induction of apoptosis by human Nbk/Bik, a BH3-containing protein that interacts with E1B 19K. Mol. Cell. Biol. 16: $5857-$ 5864

Han Z, Chatterjee D, He DM, Early J, Pantazis P, Wyche JH and Hendrickson EA (1995) Evidence for a G2-checkpoint in p53-independent apoptosis induction by X-irradiation. Mol. Cell. Biol. 15: 5849-5857
Han Z, Chatterjee D, Early J, Pantazis P, Hendrickson EA and Wyche JH (1996a) Isolation and characterization of an apoptosis-resistant mutant of human leukemia HL-60 cells that has switched expression from $b c l-2$ to $b c l-x$. Cancer Res. 56: 1621-1628.

Han Z, Malik N, Carter T, Reeves WH, Wyche JH and Hendrickson EA (1996b) DNAdependent protein kinase is a target of a CPP32-like apoptotic protease. J. Biol. Chem. 271: 25035-25040

Han Z, Hendrickson EA, Bremner TA and Wyche JH (1997) A sequential two-step mechanism for the production of the mature $\mathrm{p} 17: \mathrm{p} 12$ form of caspase-3 in vitro. J. Biol. Chem. 272: 13432-13436

Inohara N, Ding L, Chen S and Nunez G (1997) harakiri, a novel regulator of cell death, encodes a protein that activates apoptosis and interacts selectively with survivalpromoting proteins bcl-2 and bcl-X . EMBO J. 16: 1686-1694

Ishida Y, Furukawa Y, Decaprio JA, Saito M and Griffin JD (1992) Treatment of myeloid leukemia cells with phosphatase inhibitor okadaic acid induces cell cycle arrest at either G1/S or G2/M depending on dose. J. Cell. Physiol. 150: 484-492

Jemmerson R, Johnson JG, Burrell E, Taylor PS and Jenkins MK (1991) Relative frequencies of secondary B cells activated by cognate vs othermechanisms. Eur. J. Immunol. 21: 143-151

Kiefer MC, Brauer MJ, Powers VC, Wu JJ, Umansky SR, Tomei LD and BarrPJ (1995) Modulation of apoptosis by the widely distributed bcl-2 homologue bak. Nature 374: $736-739$

Kiguchi K, Glesne D, Chubb CH, Fujiki H and Huberman E (1994) Differential induction of apoptosis in human breast tumor cells by okadaic acid and related inhibitors of phosphatase 1 and 2A. Cell Growth Differ. 5: 995-1004

Kluck RM, Wetzel-Bossy E, Green DR and Newmeyer DD (1997) The release of cytochrome c from mitochondria: a primary site for bcl-2 regulation of apoptosis. Science 275: 1132-1136

Laliberte JF and Beaudoin AR (1983) Sequential hydrolysis of the $\gamma$-and $\beta$-phosphate groups of ATP by the ATP diphosphohydrolase from pig pancreas. Biochim. Biophys. Acta 742: 9-15

Lebel D, Poirier GG, Phaneul S, St.-Jean P, Laliberte JF and Beaudoin AR (1980) Characterization and purification of a calcium-sensitive ATP diphosphohydrolase from pig pancreas. J. Biol. Chem. 255: 1227-1233

LiP, Nijhawan D, Budihardjo I, Srinivasula SM, Ahmad M, Alnemri ES, Wang X (1997) Cytochrome $c$ and dATP-dependent formation of apaf-1/caspase- 9 complex initiates an apoptotic protease cascade. Cell 91: 479-489

Lithgow T, van Driel R, Bertram JF and Strasser A (1994) The protein product of the oncogene bcl-2 is a component of the nuclear envelope, the endoplasmic reticulum, and the outer mitochondrial membrane. Cell Growth Differ. 5: 411 417

Liu X, Kim CN, Yang J, Jemmerson R and Wang X (1996) Induction of apoptotic program in cell-free extracts: requirement for dATP and cytochrome $c$. Cell 86 : $147-157$

Martin SJ, Lennon SV, Bonham AM and Cotter TG (1990) Induction of apoptosis (programmed cell death) in human leukemic $\mathrm{HL}-60$ cells by inhibition of RNA or protein synthesis. J. Immunol. 145: 1859-1867

Martin SJ, Finucane DM, Amarante-Mendes GP, O'Brien GA and Green DR (1996) Phosphatidylserine externalization during CD95-induced apoptosis of cells and cytoplasts requires ICE/CED-3 protease activity. J. Biol. Chem. 271: 2875328756

Minn AJ, Velez P, Schendel SL, Liang $H$, Muchmore SW, Fesik SW, Fill M and Thompson CB (1997) Bcl- $x_{L}$ forms an ion channel in synthetic lipid membranes. Nature 385: 353-357

Monaghan P, Robertson D, Amos TAS, Dyer MJS, Mason DY and Greaves MF (1992) Ultrastructural localization of Bcl-2 protein. J. Histochem. Cytochem. 40: 18191825

Nicholson DW, Ali A, Thornberry NA, Vaillancourt JP, Ding CK, Gallant M, Gareau Y, Griffin PR, Labelle M, Lazebnik YA, Munday NA, Raju SM, Smulson ME, Yamin TT, Yu VL and Miller DK (1995) Identification and inhibition of the ICE/CED-3 protease necessary for mammalian apoptosis. Nature 376: $37-43$

Oltvai ZN, Milliman CL and Korsmeyer SJ (1993) Bcl-2 heterodimerizes in vivo with a conserved homolog, bax, that accelerates programed cell death. Cell 74: 609619

Salvesen GS and Dixit VM (1997) Caspases: intracellular signaling by proteolysis. Cell 91: $443-446$ 
Sato T, Hanada M, Bodrug S, Irie S, Iwama N, Boise LH, Thompson CB, Golemis E, Fong L, Wang H-G and Reed JC (1994) Interaction among members of the Bcl-2 protein family analyzed with a yeast two-hybrid system. Proc. Natl. Acad. Sci. USA 91: 9238-9242

Schendel SL, Xie Z, Montal MO, Matsuyama S, Montal M and Reed JC (1997) Channel formation by antiapoptosis protein Bcl-2. Proc. Natl. Acad. Sci. USA 94: $5113-5118$

Schlegel J, Peters I, Orrenius S, Miller DK, Thornberry NA, Yamin T-T and Nicholson DW (1996) CPP32/apopain is a key interleukin $1 \beta$ converting enzyme-like protease involved in Fas-mediated apoptosis. J. Biol. Chem. 271: 1841-1844

Solter AW and Handschumacher RE (1969) A rapid quantitative determination of deoxyribonucleoside triphosphates based on the enzymatic synthesis of DNA. Biochim. Biophys. Acta 174: 585-590

Tewari M, Quan LT, O'Rourke K, Desnoyers S, Zeng Z, Beidler DR, Poirier GG, Salvesen GS and Dixit VM (1995a) Yama/CPP32 $\beta$, a mammalian homolog of CED-3 is a CrmA-inhibitable protease that cleaves the death substrate poly(ADP-ribose) polymerase. Cell 81: 801-809
Tewari M, Reidler DR and Dixit VM (1995b) CrmA-inhibitable cleavage of the 70-kDa protein component of the $\mathrm{U} 1$ small nuclear robonucleoprotein during Fas- and tumor necrosis factor-induced apoptosis. J. Biol. Chem. 270: 18738-18741

Wang K, Yin X-M, Chao DT, Milliman CL and Korsmeyer SJ (1996) BID: a novel BH3 domain-only death agonist. Genes Dev. 10: 2859-2869

Yang E and Korsmeyer SJ (1996) Molecular thanatopsis: a discourse on the BCL-2 family and cell death. Blood 88: 386-401

Yang E, Zha J, Jockel J, Boise LH, Thompson CB and Korsmeyer SJ (1995) Bad, a heterodimeric partner for $\mathrm{bcl}-\mathrm{x}_{\mathrm{L}}$ and $\mathrm{bcl}-2$, displaces bax and promotes cell death. Cell 80: 285-291

Yang J, Liu X, Bhalla K, Kim CN, Ibrado AM, Cai J, Peng T-I, Jones DP and Wang X (1997) Prevention of apoptosis by bcl-2: release of cytochrome $c$ from mitochondria blocked. Science 275: 1129-1132 